【顎咬合誌, 15(4)：159〜166，1994】

\title{
顎関節症における下顎位置整復治療法
}

第 2 報 咬頭嵌合位を消失した顎関節症症例について

\author{
柳 生 嘉 博* 谷 勅 行*
}

\section{Treatment Methods for Repositionning the Mandible with Temporomandibular Dysfunction}

Part II A Case where the Position of Maximum Intercuspation had been Lost

\section{Yoshihiro Yagyu* and Noriyuki Tani*}

\begin{abstract}
Although there are various theories concerning the treatment of temporomandibular dysfunction, owing to the special nature of this disease, there is no single standard treatment method. Even though the effectiveness of the bite plane, which has been used for many years, is well known, it is not appropriate for all cases. In addition, it is common knowledge that relapses occur when its use is terminated.
\end{abstract}

Having many questions about these points, we have been carrying out research for several years. As a result, we arrived at the conclusion that favorable treatment results could not be attained without resolving the problem of the positional relationships of the temporomandibular joint region.

Conventional bite plane fabrication methods have been carried out without considering positional relationships of the temporomandibular joint. We concluded that the above problem may have arisen for this reason. We are making this report since we were able to attain good results with case where we incorporated a treatment plan taking into consideration these issues.

\section{緒 言}

顎関節症の病因には，現在まで多数研究報告が なされ ${ }^{1 \sim 6,8 \sim 14)}$, 症状所見から分類される方法 ${ }^{1,2)}$, 機能的異常所見から分類される分類法 ${ }^{3,4)}$, さらに 精神心理的所見から分類される分類法等 ${ }^{5,6)}$ が報 告されている。しかし, 臨床的には前述の分類が 重複している症例も多く報告されており，こう いったところが本症の診断・治療の困難さを物 語っている7). 補経学的立場からみると, 咬合と本 症の係わりについて否定的な意見を述べる人もい
る。しかし，多くの臨床を手掛けるわれわれ臨床 家にとっては，必ずしも否定的になれないところ がある.

今回報告する症例は，咬合高径が消失し，咬頭 嵌合位が不安定となり，顎機能障害を発症し，咬 合が関係していると判断された症例である。さら に，咬頭嵌合位の消失に伴い下顎位の位置異常を 引き起こしていると考えられる ${ }^{8)}$.そこで, 1991 年 広島において開催された W. C. P., I. C. Pにおい て第 1 報を報告した，われわれの顎関節症治療法 の基本である下顎位置整復治療法 ${ }^{9,10,14)}$ を実施す ることにより，良好な回復を得たので報告する。

$*$ 明海大学歯学部㐘科補経学第一講座 


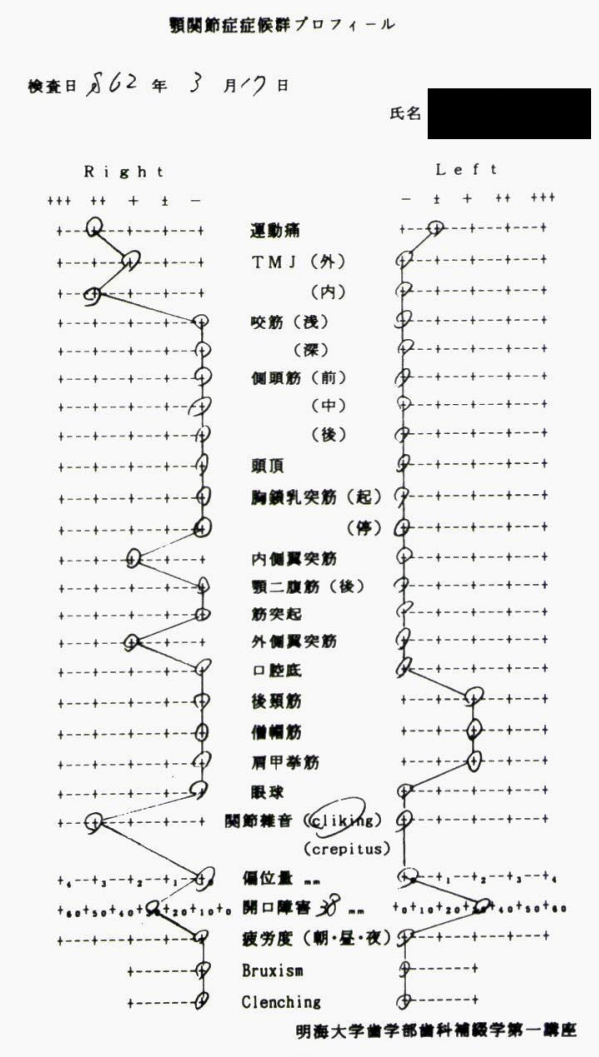

図 1

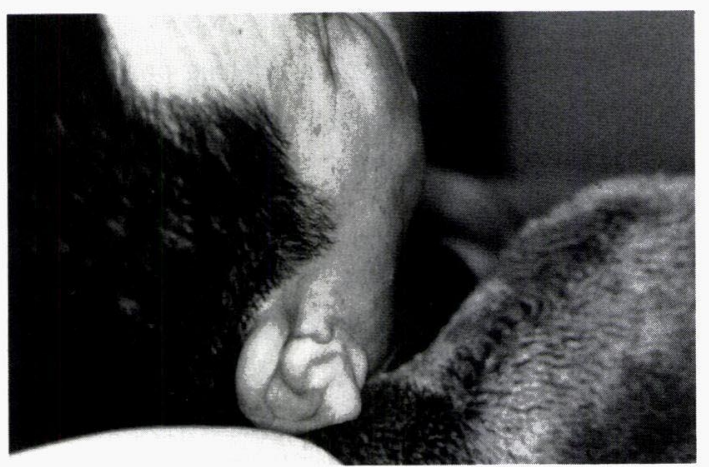

図 2

症例

患 者: 男性, 68 歳.

初診日：昭和 62 年 3 月 17 日.

主 訴：右の顎が痛い。

既往歴：

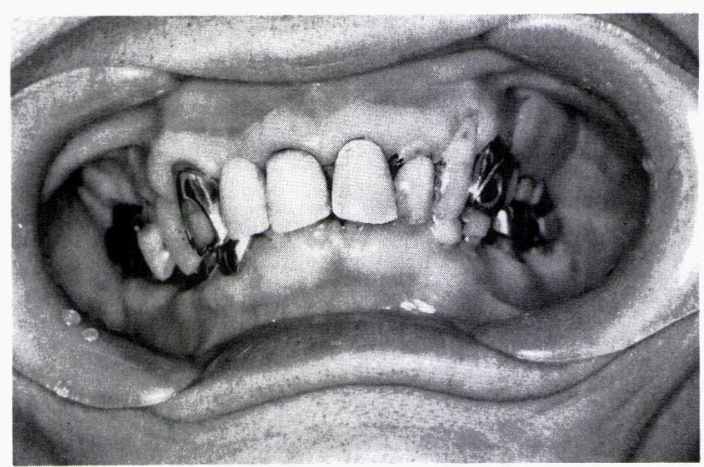

図 3

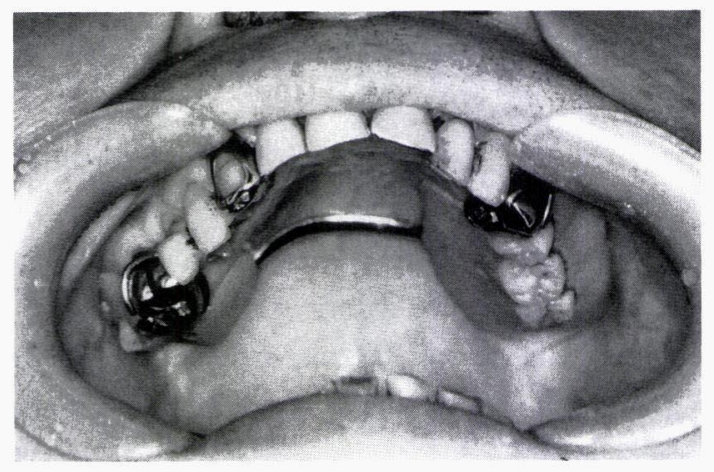

図 4

現病歴；坂戸市の根本歯科医院より本学を紹介 される 3 日前に右顎関節部にガキというような音 がして痛みが発症し, 同部が腫れてきた.そして 口が少ししか開かなくなった。また，耳の中まで 痛くなり，心配になり根本歯科医院に相談したと ころ本学を紹介された，過去に顎関節部に同様な 症状は，経験したことがないとのことであった。

家族歴：特記事項なし。

口腔内所見：7|567 は, 欠損しており局部床

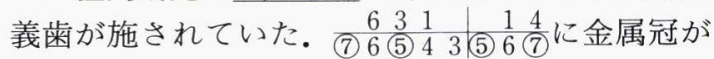
施されていた。

顎関節機能：図 1 に示すごとく, 開口障害, 筋 肉の痛み, 関節雑音等があきらかに認められた。 また，図 2 にられるように右側頑関節部に腫脹 が認められた。さらに, 咬合関係は, 図 3 に示す ごとく過蓋咬合ぎみであり, 一見咬合が安定して いるようであるが，図4 に認められるように5 4 の口蓋側機能咬頭が, 完全に摩耗しており, 咬頭 嵌合位を得られない状態であった。

一般；特になし。 


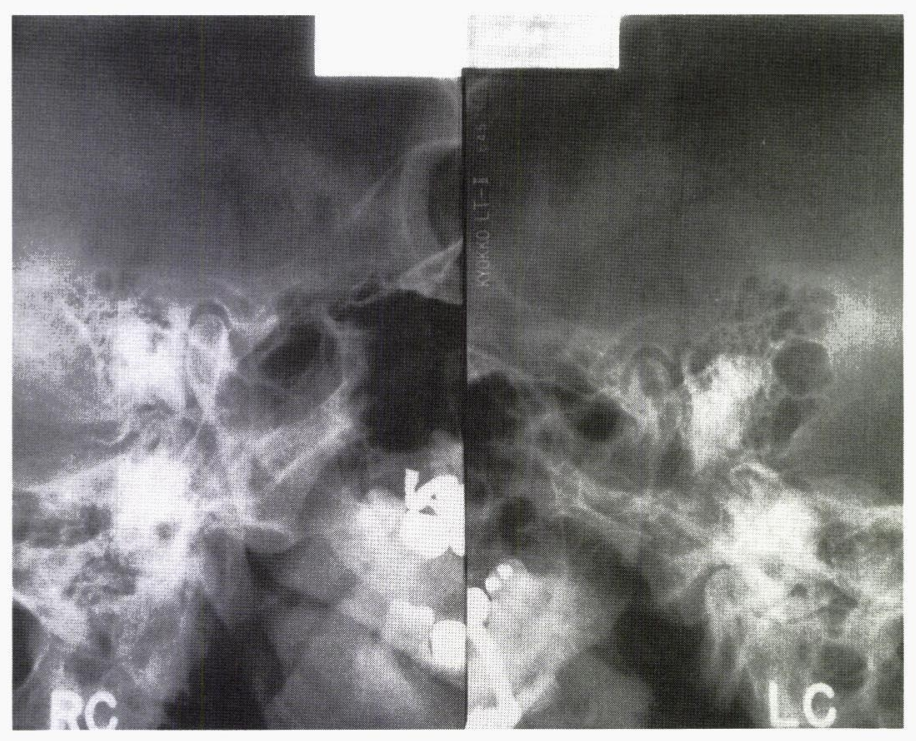

図 5

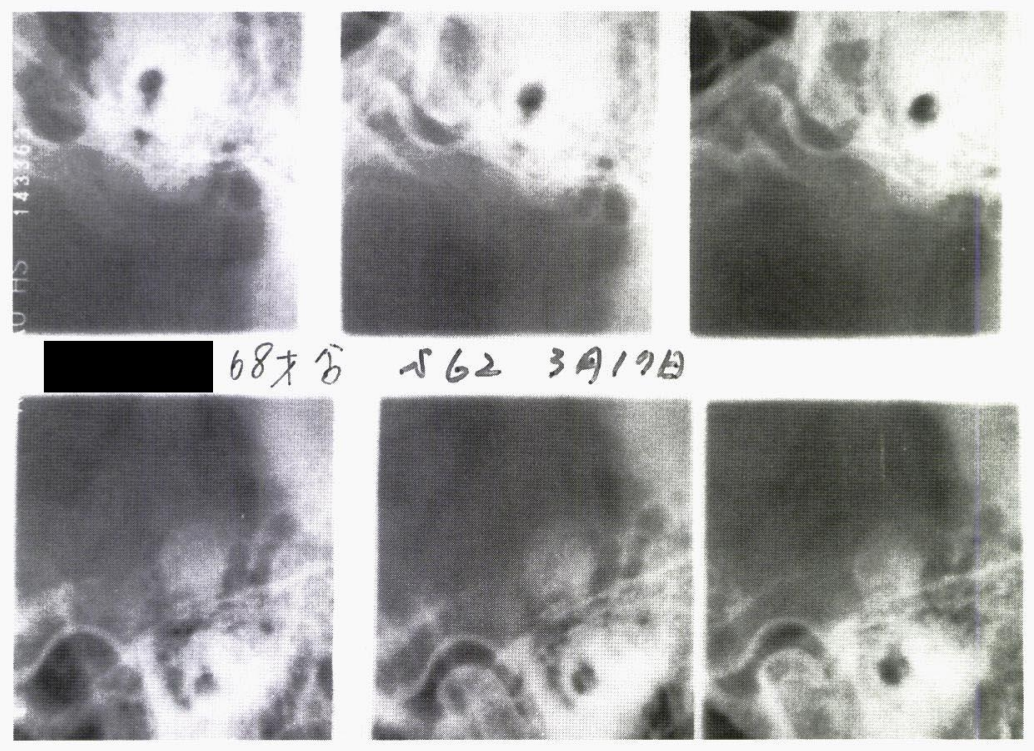

図 6

\section{X線所見 :}

シュラー氏法; 閉口状態における顎関節の位置 関係は, 右側は上下的には顆頭の関節窩への接近 はなく,やや後方への移動を認める。左側は，逆 にやや前方への顆頭の移動を認めた．器質的な変 化については, 慢性的な炎症, 破壊等は認められ なかった（図 5 )。

AXA；シュラー氏法とほぼ同様な所見を示し
ていた (図6).

臨床的診断：上記の所見から, 咬合関係の不安 定による顎関節症と診断された。そして，X線所 見, 運動機能, 筋肉診等から慢性化した病態では なく初期の段階と判断される.

処置経過：諸診査, 問診, 口腔内所見の結果か ら治療方針は, 咬頭嵌合位の安定を求めるのが最 適であるとの結論に達した。すなわち, X線所見 


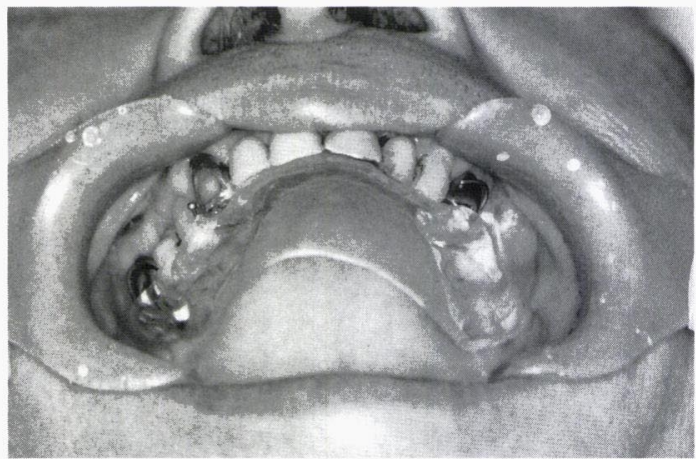

図 7

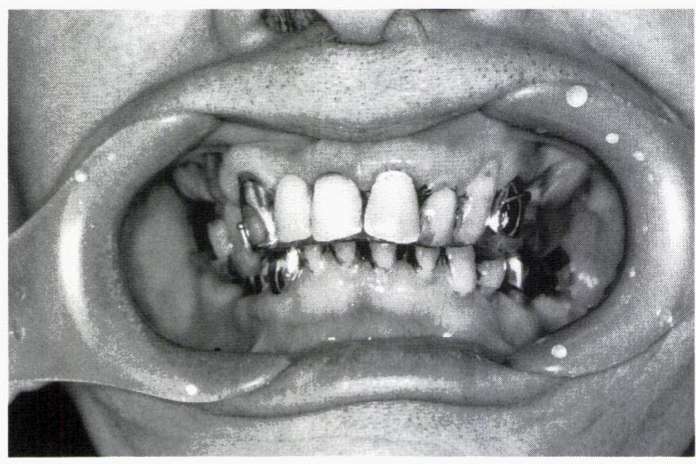

図 8

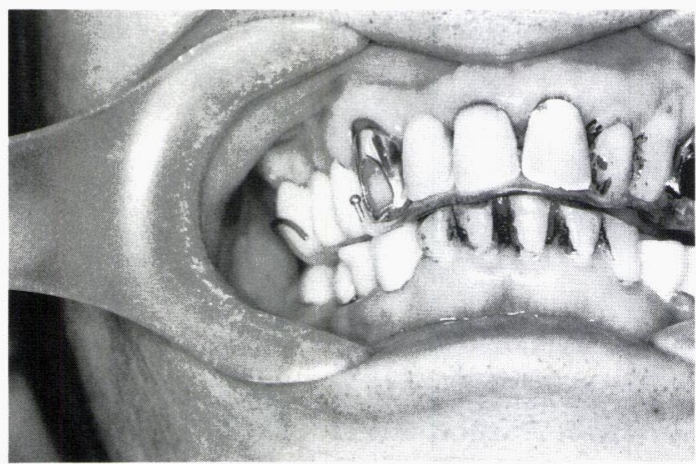

図 9

より咬合挙上量は, それほど必要とせず, 右側澦 関節部において $90^{\circ}$ 下方 $0.5 \mathrm{~mm}$ 程度，左側は $90^{\circ}$ 下方 $1 \mathrm{~mm}$ の挙上量に決定した.

初 診：昭和 62 年 3 月 17 日.

使用中の局部床義歯の調整と軟組織処置, X線 撮影 (シュラー氏法, AXA), 口腔内軟膏処方, 諸 検査を行う。

同年 3 月 31 日：Bite Plane 用精密印象を寒天

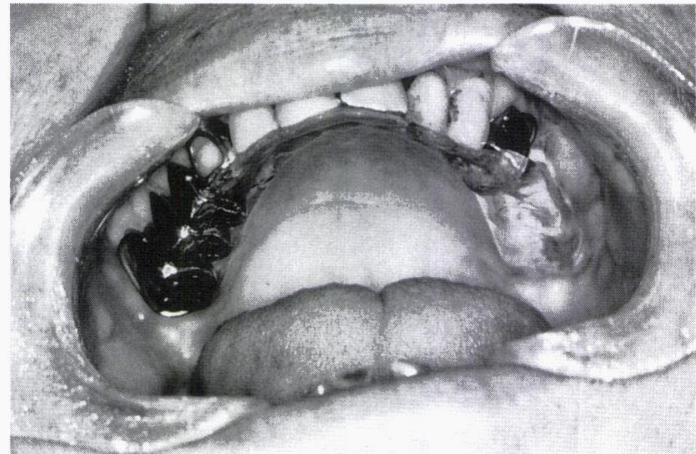

図 10

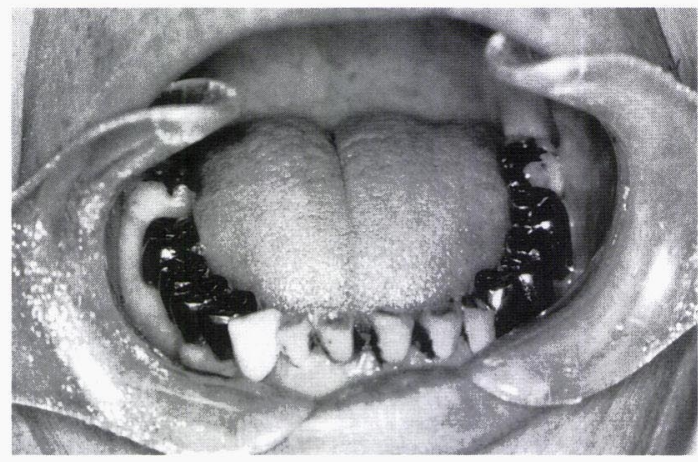

図 11

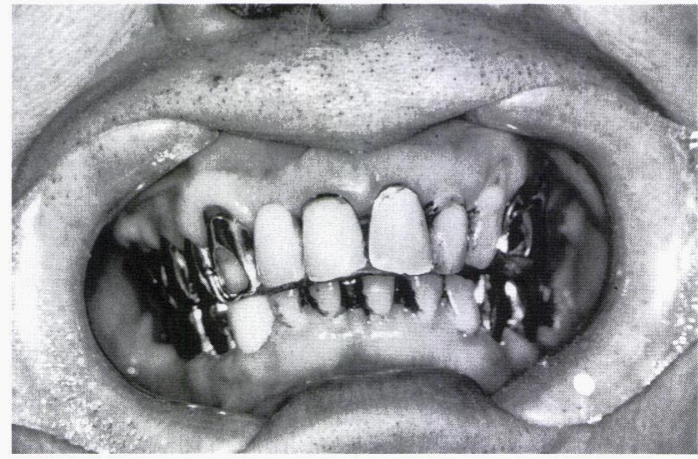

図 12

印象にて上下顎に行った。スライドマチックフェ イスボウにてフェイスボウトランスファと咬合採 得を行った. 作業用模型は, コンダイル・リポジョ ナー咬合器（テレダインハノー社製）に咬頭嵌合 位に近い位置にて装着を行った。そして, 前述の 挙上量を同咬合器を調節することにより付与し, Bite Plane の製作を行った.

同年 5 月 1 日: Bite Plane set (図 7, 8). 同年 5 月 15 日：Bite Plane ajustment 滑走を 


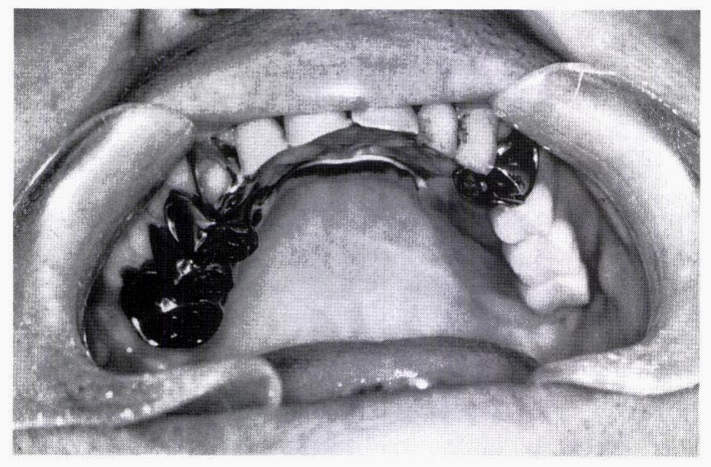

図 13

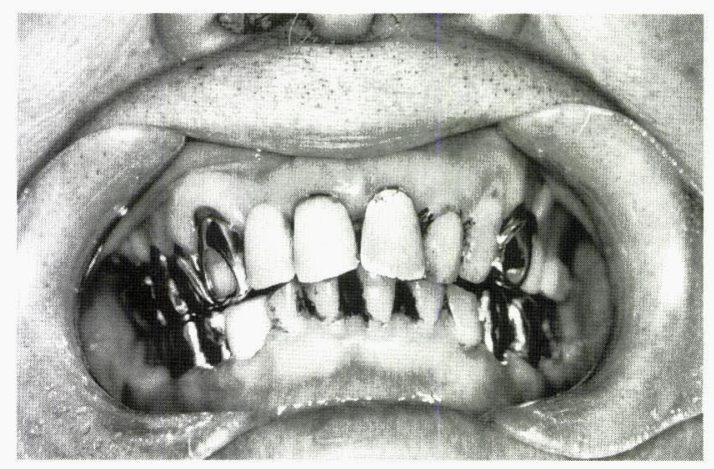

図 14

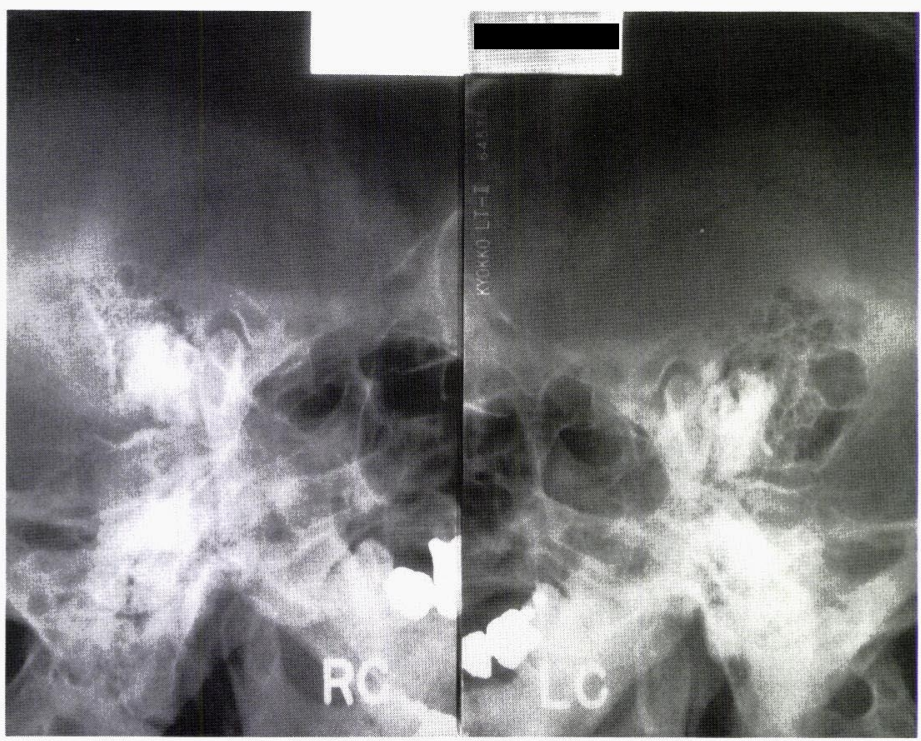

図 15

生じている所の咬合調整を行った。軟組織処置と 口腔内軟膏を処方した。

同年 6 月 2 日: Bite Plane ajustment.

この時点における症状は,・QFB $50 \mathrm{~mm}$ (+ 12), ・右側 TMJ の痛み消失（特に耳の痛み）,

- 右側頡関節雑音消失, ・腫脹消失, ・下㖽運動が しやすくなり，左側で嚙めるようになったとのこ と, - 筋肉触診, 右内側翼突筋 $(+)$, 右外側翼突 筋 $(+)$, その他の筋 $(-)$, ・左側に肩凝りがある (以前より存在).

同年 6 月 17 日：7654|の Bite Plane ajustment 咬合接触の数を増やすべく調整を行う。こ の時点で症状の発症は認められず，咬合も安定を 得られたので次のステップに進む旨説明を行っ
た。

同年 7 月 1 日: (5) 6(7)Bridge 除去, 失形, TEK, $\sqrt{4}$ 生形, TEK.

上記の TEK は解剖学的形態とした。

同年 7月 17 日：(7) 6 (5) 43 の冠扔よび Bridge を除去し TEK を作成するが, 図 9 に見られるよ うに TEK 形態を煩側方向に咬合面を拡大し，上 顎の歯と咬合ができる形態とした。

同年 7月 30 日：54 生形, TEK.

同部 TEK の口蓋支持咬頭を与え, $7 \sim 3$ との 咬合を確保し咬頭嵌合位が安定するようにした。 この時点で右側方での咬合と筋訓練を兼ねた運動 を行うことを指示した。

同年 8 月 17 日：TEK 咬合調整. 

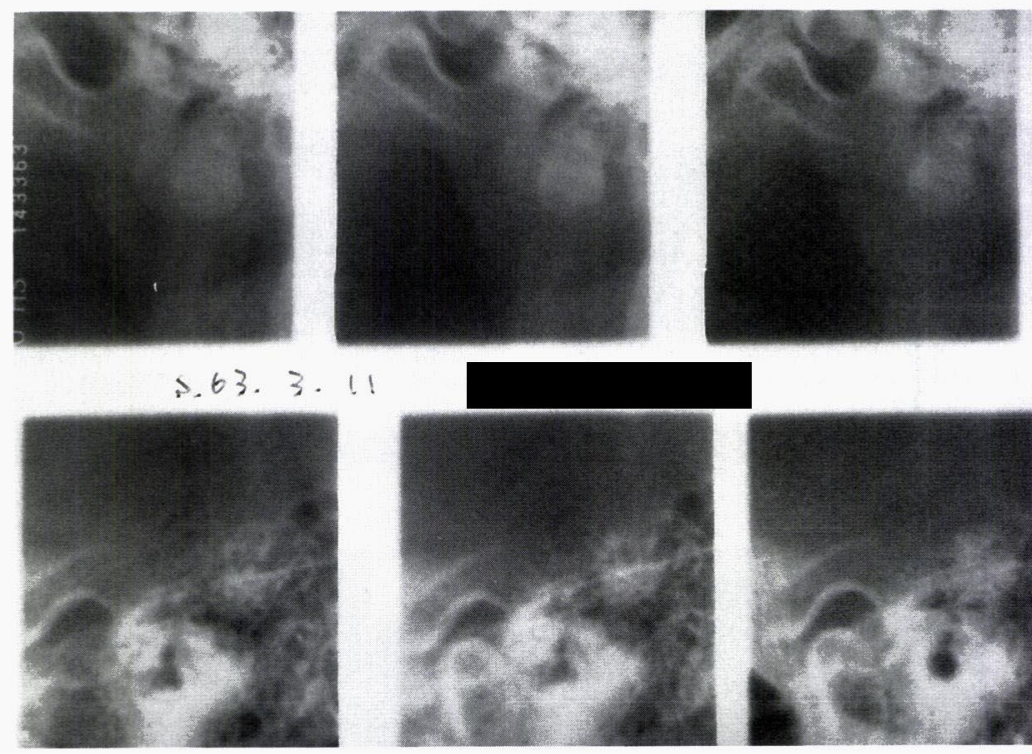

図 16

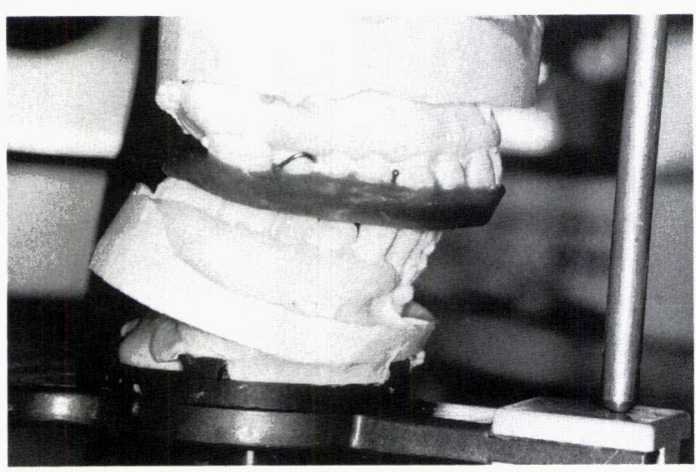

図 17

右側側方にて, 左側 Bite Plane の 7 に咬合干 渉を認めた。また，6が, 7 ～30 TEK との干 渉を認めたのでこれを調整した。

同年 9 月 1 日：観察，右側方移動がかなり ムーズに行えるようになったとのことである。

同年 9 月 29 日： 6 冠除去, 形成, TEK.

同歯の咬合が不適性であったので，支持咬頭を 明確にし咬合を確保した。この時点で下顎運動は 改善された。

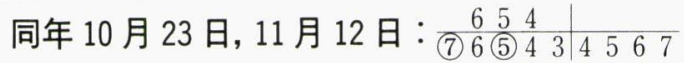
の本印象を行った。

同年 11 月 28 日：咬合採得，ディナーマーク II システムを用いフェイスボウトランスファーを行 い，咬合採得を行った。
同年 12 月 17 日: $\frac{654}{67} 6$ (5) (4) $3 \mid 4$ (5) 6 (7) 仮着（図 10, 11, 12).

昭和 63 年 1 月 14 日：観察，左側咬合が高く感 じられたが，3〜 4 日で慣れて感じられなくなっ た．現在は，良好とのことであった。

同年 1 月 23 日：装着, 咬頭嵌合位は, 安定して おり良好とのことであった。

同年 2 月 9 日：567 5 欠損の局部義歯用本印象 と咬合採得を行った。

同年 3 月 2 日：局部床義歯装着（図 13，14）.

同年 3 月 11 日：観察, X線診査および諸検査を 行う。局部床義歯は良好であったので調整は行わ なかった。検査結果は,・QFB $50 \mathrm{~mm}(+12)$, - 右内側翼突筋 $( \pm)$, - 右外側翼突筋 $(-)$, - 左 肩凝り $(-)$,・クリック音 $(-)$.

初診時の症状は，消失したとのことであった。

X線所見：レントゲン像は, 明瞭で顎関節の位 置関係もやや間隙が認められた（図 15，16）。

図 14 は, 治療完了時の口腔内を示している.こ の時点で臨床的には治療を完了と判断した。

総括

われわれは, 1975 年以来顎関節症患者の治療を 続けてきたが8 14)，当初の治療においては明確な 
治療効果を得ることができなかった。どちらかと いえば対症療法的であり, 従来型の Bite Plane を 用いても，患者がその装置の使用を中止すると再 発をすることがしばしば認められた。また，従来 型の Bite Plane では, 審美性, 日常会話，咀嚼 といった面で日常的な使用は不可能であることが 問診の結果あきらかとなった。つまり，従来型の Bite Plane 製作法には, 何らかの問題が存在する ことを示唆している. 従来型の Bite Plane 作成 方法は, 咬合器のガイドポールを術者の目安によ り挙上量を決定していた点に問題があったと考え る(図 17)。すなわち，顎関節の位置関係に異常が 認められるのであるから，その点を解決すべき治 療法か, あるいは Bite Plane 製作方法を選択す るべきである.われわれは, 1983 年と 1985 年の日 本補緅歯科学会学術大会において前述の問題点を 解決すべく Bite Plane 製作方法について発表を 行った ${ }^{9,10)}$. その製作方法の基本は, 䪽関節窩と顆 頭の位置関係を重視した Bite Plane 製作方法を 提唱した。

本報告には，そういったコンセプトを基本に治 療を行った。まず，X線診断を行い，顎関節窩と 顆頭の位置関係を診査した。そして, 関節の上下 的位置関係には問題はなく, 水平的にやや変位を 認めた。ささらに, 口腔内所見から支持咬頭の摩耗 による, 咬頭嵌合位の消失があきらかであった。 このことは, Kundert (1976) ${ }^{15)}$, Summa (1918) ${ }^{16)}$, Prentiss（1918） 17) らが以前から指摘している問 題点である.さらに高齢者によく認められる咬頭 嵌合位が確保されていない咬合においては, 顎関 節機能障害を起こし得る原因になることを報告し ている ${ }^{18)}$

本症例のごとく臨床的見地から判断しても，咬 合関係の不安定が関与しているといわざるをえな $い^{19,20)}$. 他方, 逆説的にみても本症例のごとく, 治 療を行うことにより臨床症状が改善されるのを確 認できたことが，他の報告と同様に補緅治療とり わけ咬合関係の確保の大切さを示唆してい $ろ^{21 \sim 23)}$.

\section{結論}

1. 本症例において，咬頭嵌合位を確保するこ とにより顎関節症に伴う顎関節機能障害を改善す ることができた。

2.下顎位位置整復治療法が, 有効であったこ とを確認した。

本研究にご協力を戴いた，患者および資料収集を 手助けしてくれた三上智弘医局員に感謝致します。

\section{参考文献}

1) Berry, D.C. : Mandibular dysfunction pain and chronic minor illness. Brit. Dent. J. 127 : 170 174, 1969.

2) Agerberg, G. and Carlsson, G. E. : Functional disorders of the masticatory system, II Symptoms in relation to impared mobility of the mandible as judged from investigation by questionnaire. Acta. Odont. Scand. 31:335 〜345, 1973.

3) Öberg, T. et al.: The Temporomandibular joint : A morophologic study on a human autopsy material. Acta. Odont. Scand. 29: 349 384, 1971.

4) Weinberg, L. A. : Correlation of temporomandibular dysfunction with radiographic findings. J. Prosthet. Dent. 28:519 539, 1972.

5) Dowson, P. E. : Evaluation, diagnosis and treatment of occlusal problems. C. V. Mosby, St. Lousis : 1 104, 1974.

6) Molin, C. et al. : Frequency of symptoms of mandibular dysfunction in young Swedish men. J. Oral Rehabil. $3: 9 \sim 18,1976$.

7）坂東永一, 三谷英夫, 上村修三, 他: 顎機能異 常一新しい診断システムと治療方針。: 55-82, 医歯薬出版 (東京), 1993.

8）佐々木英博, 笹田和裕, 谷 勅行, 他: 補経学 的処置により軽快した Artholosis Temporomandibularis の 1 症例. 城歯大紀要 4(2): 393-400, 1975.

9）吉本 理, 若林 徹, 永井泰二, 他: 咬合挙上 板の製作法について. 補緅誌 28 ( 1$), 127,1984$.

10）吉本 理, 若林 徹, 永井泰二, 他: 咬合挙上 板の製作法について 第 2 報ハノー社製コンダ イルリポジショナーを用いて. 補綴誌 29(6): 253-254, 1985 .

11）村上 亘, 谷 栜行, 笹田和裕, 他: 顎関節症 の 1 症例一特に筋電図学的観察について一. 城 
歯大紀要 5 （2）：309-318，1976.

12）谷 勅行, 村上 亘, 佐々木英博: Mandibular Kinesiograph を顎関節症の診断に応用した 4 症例．城歯大紀要 7 （2）:319-338，1978.

13) Tani, N., Nemoto, S., Miyake, H. : Statistical of Patients with Temporomandibular Joint Dysfunction by CMI Classification. Bull. Josai Dent. Univ., $14(2 \cdot 3): 362-369,1985$.

14) Tani, N., Seki, M., Tanaka, S. : Condyle repositioning therapy in temporomandibular arthrosis-The first report, considerations about syndromes-. J. Meikai Univ. Dent., 21 (1), 256-261, 1992.

15) Kundert, M.: Zum Aussagewertdes kieferglenkröntgenbildes nach Sehüller füdieg elenkbezogene Okklusions diagnostik, Schweiz, Mschr. Zahheilk 86 : 393-412, 1976.

16) Summa, R. : The importance of the interarticular fibro-cartilage of the temporomandibular articulation. Dent. Cosmos 60:512514, 1918.

17) Prentiss, H. J. : A preliminary report upon the temporomandibular articulation in the human type. Dent. Cosmos, 60, 505-512, 1918.

18）鈴木哲也, 熊谷 宏, 内田達郎, 他：高齢者の
咬合支持状況に関する研究．補綴誌 $38 ： 476-$ 484, 1993.

19）古屋良一：咬合-診断，治療のために，顎機能異 常における咬合異常について一咬頭嵌合位の異 常による症例を中心に一. 補経臨床 別冊：217 $-227,1984$.

20）向田 吉範，伊藤 裕，荒木章純，他：顎関節症 患者の咬合接触状態と顎関節症症状について。 補緅誌 39：366-378，1995.

21）中野雅徳, 久保吉廣, 坂東永一: 顎機能異常を 惹き起こす歯の Guide について。顎機能 $2 ： 7$ $-12,1983$.

22）中野雅徳, 近藤一雄, 坂東永一：歯の Guide と 顎機能. 䫁機能 $2: 151-156,1983$.

23）竹中 誠, 竹花庄治, 丸山 健, 他：顎関節症 状自覚者の咬合接触状態について. 補綴誌 35 ： 1195-1204, 1991.

\section{別刷請求先：柳生嘉博}

